\title{
Evaluation of $\mathrm{BOD}_{5}$ and $\mathrm{COD}_{\mathrm{cr}}$ in Water of a National Nature Reserve in Southwestern Slovak Republic
}

\author{
Jaroslav Noskovič, Mária Babošová*, Jana Ivanič Porhajašová \\ Department of Environmentalism and Zoology, Faculty of Agrobiology and Food Resources, \\ Slovak University of Agriculture in Nitra, Tr. A. Hlinku 2, 94976 Nitra, Slovakia
}

Received: 31 May 2016

Accepted: 14 December 2016

\begin{abstract}
In 2010, 2011, and 2013 we assessed the water of the Čičov Oxbow National Nature Reserve in the southwestern part of the Slovak Republic for concentrations of organic substances. Collections of samples were realized regularly at monthly intervals, always about in the half of the month. Sampling sites were determined in order to assess the impact of natural and anthropogenic source of surface water quality. The results were compared from the limit values set out in Government Regulation No. 269/2010 Coll. The average value of $\mathrm{BOD}_{5}$ for the whole period was $1.58 \mathrm{mg} \mathrm{O}_{2} \mathrm{dm}^{-3}$. The highest average concentration of biodegradable organic matter was in February and the minimum in May. Depending on the sampling site, we found the highest average value for the whole monitored period in the northeastern part of Čičov Reserve, and the lowest in the sampling site situated approximately $150 \mathrm{~m}$ from the mouth of Čilizian Stream in the reserve. The average value of $\mathrm{COD}_{\mathrm{Cr}}$ for the entire monitored period represented $60.69 \mathrm{mg} \mathrm{O}_{2} \mathrm{dm}^{-3}$. Depending on the time of sampling, minimum average value was in February and maximum in September. Depending on the sampling site, we found the highest average value for the whole monitored period in the sampling site located approximately $150 \mathrm{~m}$ from the mouth of the Čilizian. The average value of the $\mathrm{BOD}_{5} / \mathrm{COD}_{\mathrm{Cr}}$ ratio during the years 2010, 2011, and 2013 was 0.026 .
\end{abstract}

Keywords: organic matters, oxbow, Slovak Republic, water quality, surface water

\section{Introduction}

Organic matter in the water can be of natural or anthropogenic origin [1]. For their determination are the most extended indirect laboratory methods based on biological or chemical oxidation of organic matter in water - determination of biochemical and chemical oxygen demand [2]. Biochemical oxygen demand (BOD)

*e-mail: Maria.Babosova@uniag.sk is defined as the amount of dissolved oxygen that is consumed upon the biochemical decomposition of organic matter by microflora under aerobic conditions at particular temperature $\left(20^{\circ} \mathrm{C}\right)$, for a period of time (five days) [3, 4]. Determining BOD is a normal part of the chemical analysis of surface and waste waters and one of the basic parameters as assessing the effectiveness of biological wastewater treatment and assessing the biodegradability of organic substances. The value of $\mathrm{BOD}_{5}$ in surface water depends on the nature of the flow, conditions for aeration, type and degree of contamination, and the quantity of 
the flow-discharged wastewater [5-6]. Chemical oxygen demand (COD) represents an amount of oxygen derived from potassium dichromate, which is required for the oxidation of organic compounds contained in 11 of water [7-8]. It is a measure of the content of substances capable of chemical oxidation and is used for estimating organic pollution of water [9]. In determining COD, the concentration of organic matter is considered by the amount of oxidizing agent, which under certain conditions is required for its oxidation [10]. COD is caught by organic matter in the oxygen equivalents, which has importance in biological wastewater treatment and self-cleaning in the flow, thus in biological processes consuming oxygen [11]. For oxidation we used either dichromate or potassium permanganate [12-14]. Accordingly, the result is indicated as $\mathrm{COD}_{\mathrm{Cr}}$ or $\mathrm{COD}_{\mathrm{Mn}}[15]$

\section{Material and Methods}

\section{Study Area and Sampling Stations}

Čičov Oxbow National Nature Reserve $\left(47^{\circ} 46^{\prime} \mathrm{N}\right.$ $\left.17^{\circ} 43^{\prime} \mathrm{E}\right)$ is the left-hand oxbow of the Danube River, which is separated from the main stream by a dam. It is located on the Danubian Plain in the most wooded part of the protected landscape area, $30 \mathrm{~km}$ from Komárno direction to Bratislava, in the cadastral area of Čičov and Kl'účovec at an altitude of $110 \mathrm{~m}$, belonging to the Danube River basin. The national nature reservation was announced in 1964 with an area of 79.8715 ha, water area of 79.87 ha, and a protective zone of 55.25 ha. Čičov Oxbow is considered to be the largest lake in the oxbow of the river in Slovakia. The average water depth is about $3 \mathrm{~m}$, maximum measured depth was $7.5 \mathrm{~m}$. The bank is divided by small peninsulas and bays. It is an important habitat for aquatic and wetland communities, which are characteristic of the meadow forests along the Danube with 24 kinds of fish, more than 100 species of birds, and several other rare species of animals and plants [16]. The area is particularly influenced by the flow of the Danube, from which oxbow water is fed by subsurface seepage. Depending on the water level, the surrounding area is waterlogged and flooded at high states. From midsummer the groundwater is declining because evaporation dominates over precipitation. By Rye Island the water opens into the oxbow Vrbina-Medved'ov channel and Cilizian Stream. It is an area of rain-snow runoff type, with the accumulation of water in December-January, with high water levels in February-April. The geological structure consists mostly of Neogene clays and pannonian sediments of the lake, covered by quaternary Holocene alluvial sediments of gravel, sand, loess, and floodwaters. The basic quaternary elements are: fluvial-wetland sediments with organic additives and fluvial-alluvial sediments in the lowlands. In terms of soil conditions, the western part of the area is dominated by clayey soil types and in the eastern part by clay-loam soil. The main soil types are: black soils carbonate and local peat soils on carbonate alluvial sediments; alluvial gley soils on the carbonate and non-carbonate sediments; and mollicgley, mollicfluvisols, and gley on the carbonate and noncarbonate alluvial sediments. The hydrogeological basis of the area consists of quaternary sands and gravels of alluvial. Čičov Reserve is located in dry to moderately dry areas with an average annual temperature of $9.9^{\circ} \mathrm{C}$. The coldest month is January, with an average monthly temperature of $-2.1^{\circ} \mathrm{C}$ and the hottest month is July, with an average monthly temperature $20.5^{\circ} \mathrm{C}$. Average annual rainfall is $550-600 \mathrm{~mm}$, and the most precipitation falls in the months of May, June, and July (average monthly rainfall $59.3 \mathrm{~mm}$ ). The area is located in one of the windiest areas of Slovakia. Maximum speed of the wind and the windiest days occurs in winter and spring. The predominant wind direction is NW [17].

The results of chemical analysis of water, which we carried out at the Department of Environment and Zoology, Slovak University of Agriculture in 2010-13, the average concentrations of selected indicators of surface water quality in the reserve were: $\mathrm{N}_{-\mathrm{NO}_{3}^{-}}^{-}=3.92 \mathrm{mg} \mathrm{dm}{ }^{-3}, \mathrm{~N}_{-} \mathrm{NH}_{4}^{+}=0.15 \mathrm{mg} \mathrm{dm}{ }^{-3}$, $\mathrm{N}_{-} \mathrm{NO}_{2}^{-}=0.04 \mathrm{mg} \mathrm{dm}{ }^{-3}, \mathrm{P}_{-} \mathrm{PO}_{4}^{3-}=0.07 \mathrm{mg} \mathrm{dm}^{-3}$, $\mathrm{P}_{\text {Celk. }}=0.35 \mathrm{mg} \mathrm{dm}{ }^{-3}, \mathrm{pH}=7.70$, conductivity $=45.61 \mathrm{mS} \mathrm{m}^{-1}$, and $\mathrm{O}_{2}=5.19 \mathrm{mg} \mathrm{O}_{2} \mathrm{dm}^{-3}$.

\section{Collection and Processing of Samples}

Collections of samples were realized regularly at monthly intervals, always about in the half of the month during the years 2010, 2011, and 2013. Sampling sites were determined in order to assess the impact of natural and anthropogenic sources of surface water quality. Specifically, we identified eight sampling points (Fig. 1):

1. $47^{\circ} 46^{\prime} 7.17^{\prime \prime}$ north latitude and $17^{\circ} 43^{\prime} 7.56^{\prime \prime}$ east longitude, $110 \mathrm{~m}$ above sea level, located about $150 \mathrm{~m}$ from the mouth of Čilizian Stream into the reserve. Average depth is $0.31 \mathrm{~m}$.

2. $47^{\circ} 46^{\prime} 6.51^{\prime \prime}$ north latitude and $17^{\circ} 43^{\prime} 7.81^{\prime \prime}$ east longitude, $104 \mathrm{~m}$ above sea level, located $20 \mathrm{~m}$ near the mouth of the Čilizian. Average depth is $0.37 \mathrm{~m}$.

3. $47^{\circ} 46^{\prime} 5.88^{\prime \prime}$ north latitude and $17^{\circ} 44^{\prime} 0.40^{\prime \prime}$ east longitude, $107 \mathrm{~m}$ above sea level, located in the northeastern part of the reserve. Average depth is $0.43 \mathrm{~m}$.

4. $47^{\circ} 46^{\prime} 4.04 "$ north latitude and $17^{\circ} 44^{\prime} 1.87^{\prime \prime}$ east longitude, $111 \mathrm{~m}$ above sea level, located in the northeastern part with an average depth of $0.43 \mathrm{~m}$.

5. 47 46 '2.09" north latitude and $17^{\circ} 440.32$ " east longitude, $111 \mathrm{~m}$ above sea level with average depth of $0.50 \mathrm{~m}$.

6. $47^{\circ} 46^{\prime} 0.02^{\prime \prime}$ north latitude and $17^{\circ} 43^{\prime} 8.26^{\prime \prime}$ east longitude, $111 \mathrm{~m}$ above sea level and located on the first side distributary. Average depth is $0.37 \mathrm{~m}$.

7. $47^{\circ} 46^{\prime} 2.23^{\prime \prime}$ north latitude and $17^{\circ} 43^{\prime} 4.45^{\prime \prime}$ east longitude, $117 \mathrm{~m}$ above sea level, located on the second side distributary of the reserve with average depth $0.39 \mathrm{~m}$. 


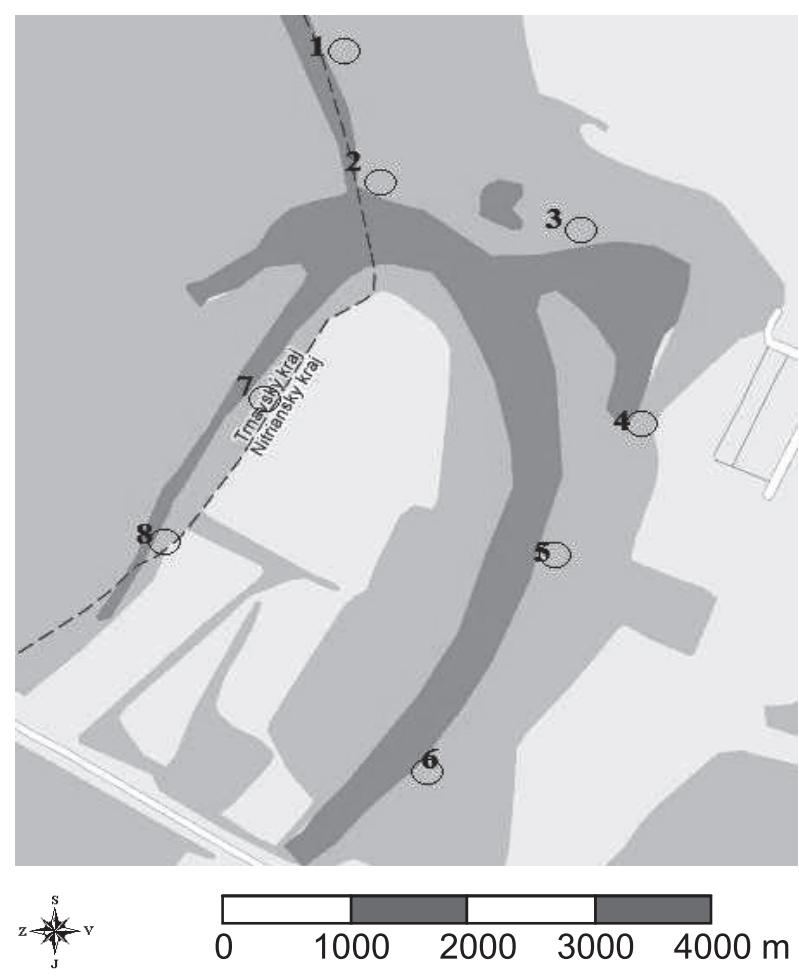

Fig. 1. Čičov Oxbow National Nature Reserve, showing the boundary between the Trnava and Nitra regions (scale: $1: 100,000)$

8. Sampling point: $47^{\circ} 46^{\prime} 3.77^{\prime \prime}$ north latitude and $17^{\circ} 43^{\prime} 5.91$ ' east longitude, $117 \mathrm{~m}$ above sea level, located in the second side distributary of reservation with average depth $0.39 \mathrm{~m}$.

In the collected water samples we determinate spectrophotometrically the biochemical oxygen demand for five days $\left(\mathrm{BOD}_{5}\right)$ on the basis of the concentration of dissolved oxygen and the chemical oxygen demand by potassium dichromate $\left(\mathrm{COD}_{\mathrm{Cr}}\right)$. The method is analogous to the ISO6060, EPA 410.A. Values of $\mathrm{BOD}_{5}$ and $\mathrm{COD}_{\mathrm{Cr}}$ are expressed in $\mathrm{mg} \mathrm{O}_{2} \mathrm{dm}^{-3}$.

To evaluate the quality of surface water in the sampling sites by individual indicators we used the values of the $90^{\text {th }}$ percentile (P90) as calculated from the measured values

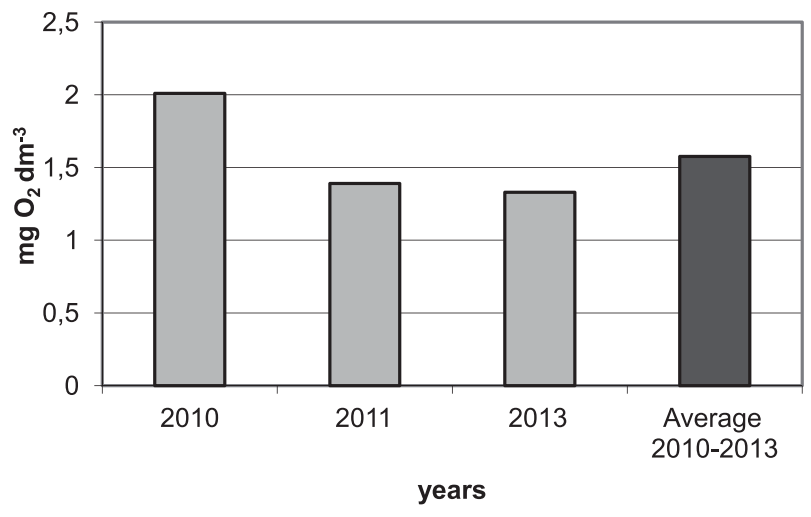

Fig. 2. Average values of $\mathrm{BOD}_{5}$ in 2010-13.

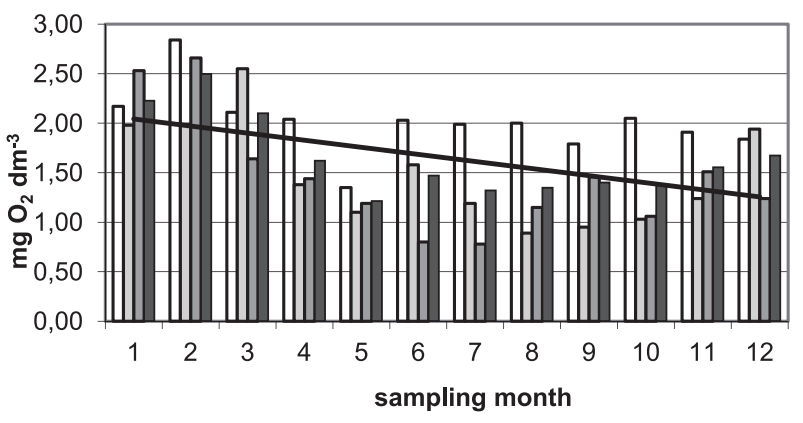

ط2010 Liniowy (Average 2010-2013)

Fig. 3. Average values of $\mathrm{BOD}_{5}$ depending on the time of sampling.

and then compared with their matching set of limit values referred to by the Regulation of the Government of the Slovak Republic No. 269/2010 Coll [18]. The results were processed by mathematical-statistical methods (using the program Statgraphics 5.0 plus).

\section{Results}

The average value of biochemical oxygen demand during the monitored period was 2.01 (2010) to 1.33 (2013) and for the whole monitored period was $1.58 \mathrm{mg}$ $\mathrm{O}_{2} \mathrm{dm}^{-3}$. Differences in average $\mathrm{BOD}_{5}$ value between years are not very significant (Fig. 2).

The results of $\mathrm{BOD}_{5}$ values depending on the sampling time shows (Fig. 3) that the highest average concentration of biodegradable organic matters was in autumn and winter. The maximum average value for the whole monitored period was in February $\left(2.66 \mathrm{mg} \mathrm{O}_{2} \mathrm{dm}^{-3}\right)$, and in 2013 we recorded its highest value $\left(4.0 \mathrm{mg} \mathrm{O}_{2} \mathrm{dm}^{-3}\right)$. We measured lower values of $\mathrm{BOD}_{5}$ in spring and summer, with minimum average value for the whole monitored period in May $\left(1.21 \mathrm{mg} \mathrm{O}_{2} \mathrm{dm}^{-3}\right)$.

Fig. 4 shows the effect of sampling sites on the value of $\mathrm{BOD}_{5}$. We found the highest average value for the whole monitored period found in sampling site No. 4 $\left(1.62 \mathrm{mg} \mathrm{O}_{2} \mathrm{dm}^{-3}\right)$, which was located in the northeastern part of Čičov Reserve. The lowest average value (1.45

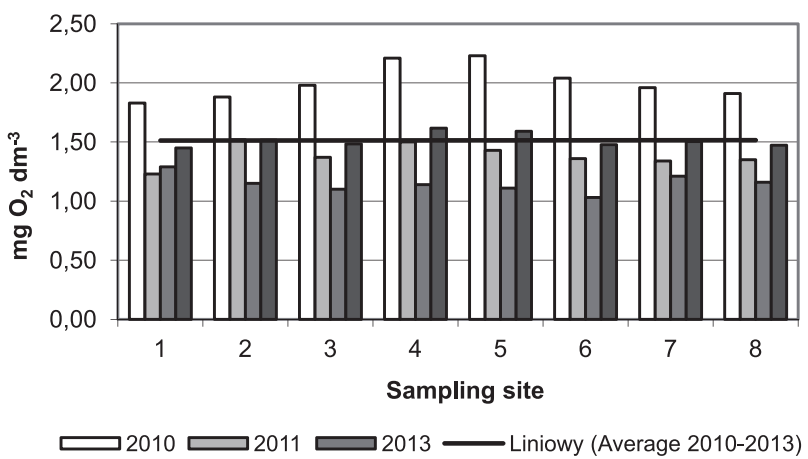

Fig. 4. Average values of $\mathrm{BOD}_{5}$ depending on the sampling site. 
Table 1. Analysis of variance for concentrations of $\mathrm{BOD}_{5}$.

\begin{tabular}{|c|c|c|c|c|c|}
\hline Effect & The sum of squares & Degrees of freedom & Mean square & F & P \\
\hline Year & 0.476 & 1 & 0.476 & 2.089 & 0.035019 \\
\hline Month & 28.26 & 12 & 2.4891 & 17.658 & 0.000000 \\
\hline Sampling site & 1.647 & 8 & 0.1203 & 1.845 & 0.092713 \\
\hline Year*Month & 36.876 & 12 & 3.3452 & 14.138 & 0.000000 \\
\hline Year*Sampling site & 4.437 & 8 & 0.6594 & 1.021 & 0.563422 \\
\hline Month*Sampling site & 16.145 & 78 & 0.2182 & 1.193 & 0.235634 \\
\hline Error & 9.789 & 75 & 0.1405 & & \\
\hline
\end{tabular}

$\mathrm{F}$ - value, $\mathrm{P}$ - value

mg $\mathrm{O}_{2} \mathrm{dm}^{-3}$ ) was in sampling site No. 1 (approximately $150 \mathrm{~m}$ from the mouth of the Cilizian). Based on the above, we can conclude that in this sampling site may have seen more favorable ratios of oxygen, resulting in a reduction of concentrations of easily degradable organic matter. In general, we can state that on average, values of BOD $_{5}$ during monitored years 2010-13 did not see marked differences among sampling sites.

The analysis of variance for $\mathrm{BOD}_{5}$ showed that a statistically highly significant effect was the year and month of collection. Significantly important was the interaction between the year and month of collection. The impact of sampling sites are shown to be statistically inconclusive. Interactions between takeoff, month sampling, and the sampling sites were inconclusive in terms of statistics (Table 1).

Calculated characteristic values of the $90^{\text {th }}$ percentile (P90) of $\mathrm{BOD}_{5}$ varied from 0.67 (sampling site No. 7) to 0.99 (sampling site Nos. 1 and 2) (Table 3), which are lower values than the recommended value of this indicator (7.0 $\mathrm{mg} \mathrm{O}_{2} \mathrm{dm}^{-3}$ ) in Government Regulation of the Slovak Republic No. 269/2010 coll.

Average values of $\mathrm{COD}_{\mathrm{Cr}}$ in the water of Čičov Reserve in 2010-13 ranged from 51.83 (2013) to 70.58 (2010) and for the whole monitored period represented $60.69 \mathrm{mg}$ $\mathrm{O}_{2} \mathrm{dm}^{-3}$ (Fig. 5).

Depending on the time of sampling, lower average values of $\mathrm{COD}_{\mathrm{Cr}}$ for the whole monitored period were found in the winter and spring period (Fig. 6), with minimal average value in the month of February (46.00

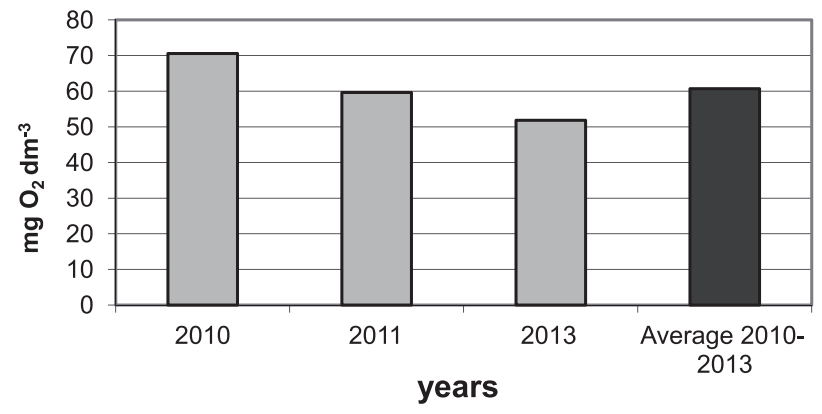

Fig. 5. Average values of $\mathrm{COD}_{\mathrm{Cr}}$ in 2010-13.

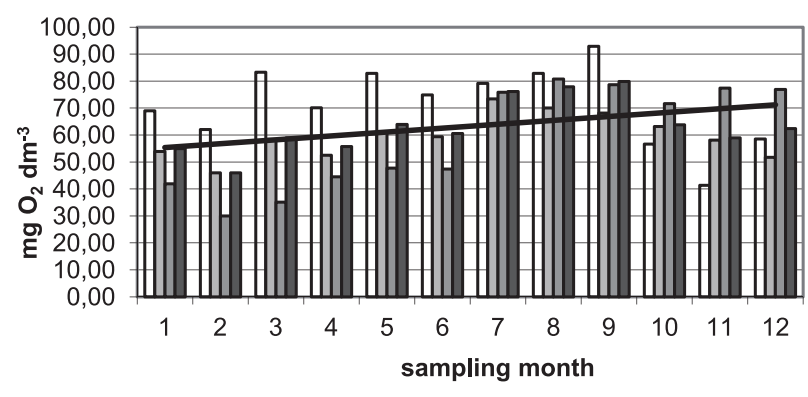

$2010 \longleftarrow 2011 \square 2013 \longrightarrow$ Liniowy (Average 2010-2013)

Fig. 6. Average values of $\mathrm{COD}_{\mathrm{Cr}}$ depending on the time of sampling.

mg $\mathrm{O}_{2} \mathrm{dm}^{-3}$ ). In this month was in 2013 we measured the absolute lowest value $\left(22.0 \mathrm{mg} \mathrm{O}_{2} \mathrm{dm}^{-3}\right)$. Contamination by organic matter is most manifested in summer months, when we recorded the highest average values of $\mathrm{COD}_{\mathrm{Cr}}$, peaking in September $\left(79.88 \mathrm{mg} \mathrm{O}_{2} \mathrm{dm}^{-3}\right)$. In this month in 2010 we saw the highest measured average value of $\mathrm{COD}_{\mathrm{Cr}}\left(92.88 \mathrm{mg} \mathrm{O}_{2} \mathrm{dm}^{-3}\right)$. And increase of values of chemical oxygen demand in the summer period could be due to higher temperature of water, accumulation of organic matter, and its intense microbial decomposition.

During the monitored period, values of $\mathrm{COD}_{\mathrm{Cr}}$ significantly affected sampling sites (Fig. 7). The highest

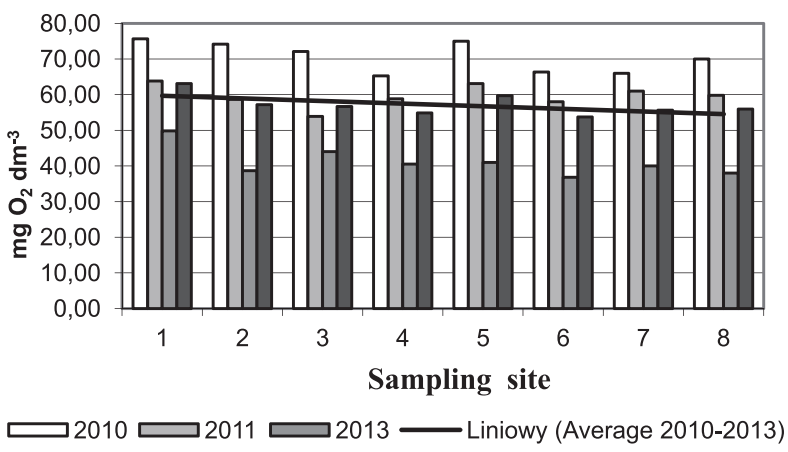

Fig. 7. Average values of $\mathrm{COD}_{\mathrm{Cr}}$ depending on the time of sampling. 
Table 2. Analysis of variance concentrations of $\mathrm{COD}_{\mathrm{Cr}}$

\begin{tabular}{|c|c|c|c|c|c|}
\hline Effect & The sum of squares & Degrees of freedom & Mean square & F & P \\
\hline Year & $1,571.0$ & 1 & $1,571.0$ & 181.513 & 0.000000 \\
\hline Month & $28,416.3$ & 12 & $2,489.5$ & 18.479 & 0.006181 \\
\hline Simple site & $1,717.2$ & 8 & 220.3 & 1.622 & 0.014823 \\
\hline Year*Month & $16,945.6$ & 12 & $1,345.3$ & 25.576 & 0.0000000 \\
\hline Year*Simple site & 827.4 & 8 & 65.9 & 0.691 & 0.000125 \\
\hline Month*Simple site & $7,356.8$ & 78 & 218.2 & 1.605 & 0.020395 \\
\hline Error & $4,082.1$ & 75 & 94.0 & & \\
\hline
\end{tabular}

F - value, $\mathrm{P}$ - value

Table 3. The calculated characteristic values of the $90^{\text {th }}$ percentile for $\mathrm{BOD}_{5}$ and $\mathrm{COD}_{\mathrm{Cr}}$.

\begin{tabular}{|c|c|c|c|c|c|c|c|c|}
\hline \multirow{2}{*}{$\begin{array}{c}\text { Calculated } \\
\text { Characteristic value }\end{array}$} & \multicolumn{9}{|c|}{ Sampling sites } \\
\cline { 2 - 10 } & 1. & 2. & 3. & 4. & 5. & 6. & 7. & 8. \\
\hline $\mathrm{BOD}_{5}$ & 0.99 & 0.99 & 0.89 & 0.90 & 0.70 & 0.89 & 0.67 & 0.87 \\
\hline $\mathrm{COD}_{\mathrm{Cr}}$ & 41.76 & 35.82 & 41.0 & 37.58 & 47.28 & 38.82 & 32.74 & 30.74 \\
\hline
\end{tabular}

average values for the whole monitored period were found in sampling site No. $1\left(63.11 \mathrm{mg} \mathrm{O}_{2} \mathrm{dm}^{-3}\right)$, approximately $150 \mathrm{~m}$ from the mouth of Čilizian Stream, which can be considered as the main source of organic matter. Higher values of $\mathrm{COD}_{\mathrm{Cr}}$ in this sampling site can probably be associated with the smallest average depth of the water $(0.31 \mathrm{~m})$.

The analysis of variance for $\mathrm{COD}_{\mathrm{Cr}}$ indicates the statistically highly significant effect of month and year; the impact of the sampling point was statistically inconclusive. It was significant interaction between the year and month of collection (Table 2).

Government Regulation No. 269/2010 Coll. provides recommended value for $\mathrm{COD}_{\mathrm{Cr}} 35 \mathrm{mg} \mathrm{O}_{2} \mathrm{dm}^{-3}$. Based on calculated values for the $90^{\text {th }}$ percentile (P90) of this indicator, we found the calculated characteristic values to exceed the recommended value in all sampling sites, except sampling sites Nos. 7 and 8 (Table 3).

Based on the average values of $\mathrm{BOD}_{5}$ and $\mathrm{COD}_{\mathrm{Cr}}$, volatility shows that a general decrease in $\mathrm{BOD}_{5}$ $\mathrm{COD}_{\mathrm{Cr}}$ increases and vice versa (Fig. 8). In summer, the

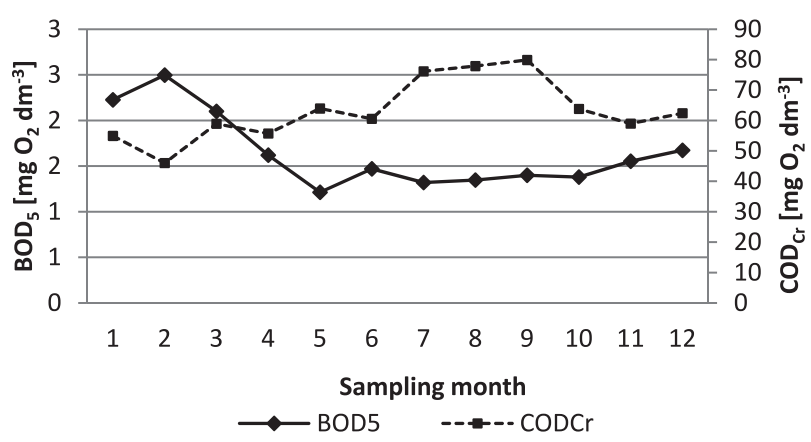

Fig. 8. Volatility average values $\mathrm{BOD}_{5}$ and $\mathrm{COD}_{\mathrm{Cr}}$ in 2010-13. water level was covered with dense growth of plants. Consequently, the amount of dead vegetation improved the nutrients, resulting in the accumulation of organic matter in the sediment and thus the organic matter in the water. Low dissolved oxygen content and intense pumping nitrogen compounds phytoplankton could be the cause of the decrease in their concentration. The average total phosphorus concentration ranged from 0.15 (year 2013) to $0.59 \mathrm{mg} \mathrm{dm}^{-3}$ (year 2010), based on the above, is a hypertrophy water (Table 4).

Table 4. Overview of the average values of the individual parameters of water quality in 2010-13.

\begin{tabular}{|c|c|c|c|c|}
\hline Parameter name & Unit & Average & $\min$. & $\max$. \\
\hline Water reaction & $\mathrm{pH}$ & 7.70 & 7.52 & 7.80 \\
\hline Conductivity & $\mathrm{mS} \mathrm{m}^{-1}$ & 45.61 & 43.72 & 46.88 \\
\hline Dissolved oxygen & $\mathrm{mg} \mathrm{dm}{ }^{-3}$ & 5.19 & 4.50 & 5.60 \\
\hline Water temperature & ${ }^{\circ} \mathrm{C}$ & 13.42 & 12.26 & 14.62 \\
\hline $\mathrm{BSK}_{5}$ & $\mathrm{mg} \mathrm{dm}{ }^{-3}$ & 1.17 & 1.08 & 1.34 \\
\hline $\mathrm{CHSK}_{\mathrm{Cr}}$ & $\mathrm{mg} \mathrm{dm}{ }^{-3}$ & 55.54 & 35.17 & 71.07 \\
\hline Total phosphorus & $\mathrm{mg} \mathrm{dm}{ }^{-3}$ & 0.35 & 0.15 & 0.59 \\
\hline $\mathrm{N}^{-\mathrm{NO}_{3}^{-}}$ & $\mathrm{mg} \mathrm{dm}{ }^{-3}$ & 3.42 & 2.40 & 3.94 \\
\hline $\mathrm{N}-\mathrm{NH}_{4}^{+}$ & $\mathrm{mg} \mathrm{dm}{ }^{-3}$ & 0.15 & 0.13 & 0.18 \\
\hline $\mathrm{N}^{-\mathrm{NO}_{2}^{-}}$ & $\mathrm{mg} \mathrm{dm}{ }^{-3}$ & 0.04 & 0.03 & 0.04 \\
\hline Chlorophyll & & $\mathrm{x}$ & $\mathrm{x}$ & $\mathrm{x}$ \\
\hline Saprobic index & & $\mathrm{x}$ & $\mathrm{x}$ & $\mathrm{x}$ \\
\hline
\end{tabular}

$\mathrm{x}-$ does not provide 
Table 5. Proportional representation of biodegradable organic matter in sampling sites in Čičov Reserve water $\left(\mathrm{BOD}_{5} / \mathrm{COD}_{\mathrm{Cr}}\right)$.

\begin{tabular}{|c|c|c|c|c|c|c|c|c|}
\hline Sampling sites & 1. & 2. & 3. & 4. & 5. & 6. & 7. & 8. \\
\hline $\mathrm{BOD}_{5}$ & 1.45 & 1.52 & 1.48 & 1.62 & 1.59 & 1.48 & 1.50 & 1.47 \\
\hline $\mathrm{COD}_{\mathrm{Cr}}$ & 63.11 & 57.17 & 56.67 & 54.86 & 59.69 & 53.72 & 55.67 & 55.94 \\
\hline $\begin{array}{c}\text { Ratio } \\
\mathrm{BOD}_{5} / \mathrm{COD}_{\mathrm{Cr}}\end{array}$ & 0.023 & 0.027 & 0.026 & 0.030 & 0.027 & 0.028 & 0.027 & 0.026 \\
\hline
\end{tabular}

In the Čičov Reserve water the ratio of $\mathrm{BOD}_{5} / \mathrm{COD}_{\mathrm{Cr}}$ during 2010-13 represented 0.026. The highest value of this ratio (0.030) was found in sampling site No. 4 and the lowest (0.023) in sampling site No. 1 (Table 5). Based on the above it can be concluded that the impact of sampling sites $\mathrm{BOD}_{5} / \mathrm{COD}_{\mathrm{Cr}}$ were expressed more significantly. In all, sampling sites of total organic content were due mainly to it being biologically difficult to break down organic matter.

\section{Discussion}

Based on our results, [19] confirmed that in the surface waters unaffected by human activities values of $\mathrm{BOD}_{5}$ range from less than $2 \mathrm{mg} \mathrm{O}_{2} \mathrm{dm}^{-3}$. Similarly, in the Olšava River basin in the Czech Republic we found its lower average value $\left(1.45 \mathrm{mg} \mathrm{O}_{2} \mathrm{dm}^{-3}\right)$ [20]. We found a higher average value of $\mathrm{BOD}_{5}\left(2.64 \mathrm{mg} \mathrm{O}_{2} \mathrm{dm}^{-3}\right)$ in the water of the Zittau luh Nature Reserve in southwestern Slovak Republic [21], compared with our results in the Danube River, where we found its maximum value of $4.9 \mathrm{mg}$ $\mathrm{O}_{2} \mathrm{dm}^{-3}[22]$.

In comparison with our results of $\mathrm{COD}_{\mathrm{Cr}}$, we found lower average value in the Danube, in the Bratislava profile on the right bank $\left(40.0 \mathrm{mg} \mathrm{O}_{2} \mathrm{dm}^{-3}\right)$ [22]. According to [23] an important source of organic matter can be hydrophytes, which increase the digestion of nutrients in Čičov Reserve water. Similar findings of the dynamics of the concentration of organic substances included $[24,25]$. The higher average value of $\mathrm{COD}_{\mathrm{Cr}}$ in 2010 $\left(70.58 \mathrm{mg} \mathrm{O}_{2} \mathrm{dm}^{-3}\right.$ ) are probably due to the accumulation of organic matter in the water and its intense microbial decomposition. The higher value of $\mathrm{COD}_{\mathrm{Cr}}$ may be associated with a lower average depth of water, which can lead to an increase in water temperature and an increase in the decomposition of organic matter, resulting in the release of organic substances from the sediments. We found similar conclusions in water of Zittau luh and Alluvium Žitavy [21, 26].

Proportional representation of biodegradable organic matter in water is estimated to form the ration of $\mathrm{BOD}_{5} / \mathrm{COD}_{\mathrm{Cr}}$. The value of this ratio is closer to 1 , and in the water it is presented as more easily degradable organic matter. Pure surface waters have a ratio of $\mathrm{BOD}_{5} / \mathrm{COD}_{\mathrm{Cr}}$ lower than $0.1[5,13]$.

On the basis of the content of nutrients (phosphorus concentration) Čičov Oxbow can be classified as hypertrophic (phosphorus content: $\geq 0.1 \mathrm{mg} \mathrm{dm}^{-3}$ ). In summer and autumn the water surface is covered with green cyanobacterial flowers so that light does not penetrate. This precludes the growth of aquatic plants, which would oxygenate the water $[27,28]$.

\section{Conclusions}

In 2010-13 in Čičov Reserve we evaluated concentrations of organic matter using biochemical oxygen demand $\left(\mathrm{BOD}_{5}\right)$ and by the indirect method, which is known as chemical oxygen demand by potassium dichromate $\left(\mathrm{COD}_{\mathrm{Cr}}\right)$. The average value of $\mathrm{BOD}_{5}$ for the whole monitored period was $1.58 \mathrm{mg} \mathrm{O}_{2} \mathrm{dm}^{-3}$. The highest average concentration of biodegradable organic matter was in the month of February and the minimum in May. Depending on the sampling site, we found the highest average value for the whole monitored period in the northeast part of Čičov Reserve and the lowest in the sampling site situated approximately $150 \mathrm{~m}$ from the mouth of Čilizian Stream. As the value of $\mathrm{BOD}_{5}$ throughout the period did not exceed a value of $5 \mathrm{mg}$ $\mathrm{O}_{2} \mathrm{dm}^{-3}$ of the trophic point of view we think it is eutrophic water. The average value of $\mathrm{COD}_{\mathrm{Cr}}$ for the entire monitored period represented $60.69 \mathrm{mg} \mathrm{O}_{2} \mathrm{dm}^{-3}$. Depending on the time of sampling, we measured minimum average values in the month of February and maximum in the month of September. Depending on the sampling site, we found the highest average value for the whole monitored period in the sampling site located approximately $150 \mathrm{~m}$ from the mouth of Čilizian Stream. The average value of $\mathrm{BOD}_{5} / \mathrm{COD}_{\mathrm{Cr}}$ ratio during the years 2010, 2011, and 2013 was 0.026 . Based on the biological evaluation of water, the National Nature Reserve is evaluated as a pure corresponding $\beta$-mezosaprobity band saprobity.

\section{Acknowledgements}

This research was supported by grant project VEGA 1/0513/12.

\section{References}

1. PIVOKONSKÝ M., KLOUČEK O., PIVOKONSKÁ L. Water Res. 40, 3045, 2006.

2. PITTER P. Hydrochemie. Prague, 568, 2009.

3. CHAPMAN, D. Water Quality Assessments, 2 ed., Chapman and Hall Ltd., London, 80. 1996. 
4. WEINER E.R. Applications of Environmental Aquatic Chemistry: A Practical Guide. 2nd ed., CRC Press, 456, 2008.

5. ŠULVOVÁ L., ŽENIŠOVÁ Z., ĎURIČKOVÁ A., FLAKOVÁ R. The oxygen regime of water gravel around Bratislava. Acta Geologica Slovaca, 1 (2), 93, 2009.

6. CHIN A.D. Water - quality engineering in natural systems. Fate and transport processes in the water environment. $2^{\text {nd }}$ ed. Hoboken: John Wiley and Sons, Inc., Hoboken, New Jersey, 472, 2012.

7. OROLÍNOVÁ M. Chemistry and the environment. The University of Trnava, 122, 2009.

8. NOLLET L.M.L., DE GELDER L.S.P. Hand book of Water Analysis, $3^{\text {rd }}$ ed., 995, 2013.

9. ŘEZNÍČKOVÁ I., HOFFMANN J., RŮŽIČKA J. Technological exercise of protecting the environment. 1 ed., Technical University in Brno, 91, 2000.

10. HETEŠA J., KOČKOVÁ E. Hydrochemie. Brno, 106, 1997.

11. FREMROVÁ L., PITTER P., BRÍZOVÁ E., FRANCE P. Documents for the Ministry of Environment to the implementation of the Protocol-overview of the methods of measurement and identification of substances monitored by the Protocol on the release and transfer registers of polluting substances in releases to water, Hydroproject, Prague, 2007.

12. WITTLINGEROVÁ Z., JONÁS̆ F. Environmental protection. $3^{\text {rd }}$ ed., Czech University of Agriculture, Prague, 131, 2004.

13. STREĎANSKÝ J. Evaluation of environmental quality. $1^{\text {st }}$ edition. Slovak University of Agricultural, Nitra, 125, 2010.

14. TOMAR M. Quality Assessment of Water and Wastewater. California, 480, 1999.

15. PAVELEKOVÁ I. Analytical chemistry for students of faculties of education. Faculty of Trnava University. Scripts, $134,2010$.

16. HANUŠIN J. Waters. Natural beauty in Slovakia, Dajama, $128,2009$.
17. VARGA P., LELKES G., FÖLDES C. The economic and social development of the village Číčov. 80, 2006.

18. GOVERNMENT REGULATION SR č. 269/2010 Z. z., aying down the requirements to achieve good water status.

19. LANGHAMMER J. The quality of surface waters and their protection. Prague, 225, 2009.

20. KAIGLOVÁ J., LANGHAMMER J. Analysis of efficiency of pollution reduction measures in rural basin using MIKE Basin model. Journal of Hydrology and Hydromechanics, 62 (1), 43, 2014.

21. NOSKOVIČ J., BEŇAČKOVÁ J., URMINSKÁ J., SZOMBATHOVÁ N. Nature Reserve Zittau luh - abiotic components. Slovak University of Agricultural, Nitra, 157, 2010.

22. ĎURÍČKOVÁA. Assessment of water quality in the Danube. IX. Young Water Conference, Banská Bystrica, 2010.

23. WANG M., HAO T., DENG X., WANG Z., CAI Z., LI $Z$. Effects of sediment-borne nutrient and litter quality on macrophyte decomposition and nutrient release. Hydrobiologia, Springer, 2016

24. PIVOKONSKÝ M., BENEŠOVÁ L., JANSKÝ B. Evaluation of water quality in the river Cidlina. Journal of hydrology and hydromechanics, 49 (6), 376, 2001.

25. ŽENIŠOVÁ Z., PANÁK D., FL'AKOVÁ R., SEMAN M. Hydrogeochemical and microbiological characteristics of gravel in Bratislava. Groundwater, 11 (2), 178, 2005.

26. NOSKOVIČ J., BABOŠOVÁ M., PALATICKÁ A., KVETANOVÁ, L. Nature Reserve Alúvium Žitavy - Water Quality. Slovak University of Agricultural, Nitra, 105, 2011.

27. BITUŠÍK P., BULÁNKOVÁ E., ČERNÝ J., FAJMOVÁ E., HALGOŠ J., KODADA J., KRNO I., ŠPORKA F., VRANOVSKÝ M. Flowing water. Slovakia biotopes. Guide to map and catalog habitats. $2^{\text {nd }}$ revised edition, Bratislava, 192, 1996.

28. BARTÍK I., TRUBENOVÁ K., HAVIAR M. List of types of surface water SR: reference site. 22, 2008. 